\title{
EVALUATION OF SAFETY AND SUCCESSFULNESS OF THE COIL EMBOLIZATION OF INTRACRANIAL ANEURYSMS
}

Snezana Lukic ${ }^{1}$, Milan Mijailovic ${ }^{1}$, Vojin Kovacevic ${ }^{2}$, Valentina Opancina

${ }^{1}$ University of Kragujevac, Serbia, Faculty of Medical Sciences, Department for Radiology

${ }^{2}$ University of Kragujevac, Serbia, Faculty of Medical Sciences, Department for Surgery

\author{
EVALUACIJA BEZBEDNOSTI I USPEŠNOSTI KOIL EMBOLIZACIJE \\ INTRAKRANIJALNIH ANEURIZMI \\ Snežana Lukić1, Milan Mijailović1 ${ }^{1}$, Vojin Kovačević ${ }^{2}$ Valentina Opančina ${ }^{1}$ \\ ${ }^{1}$ Univerzitet u Kragujevcu, Srbija, Fakultet medicinskih nauka, Katedra za radiologiju \\ ${ }^{2}$ Univerzitet u Kragujevcu, Srbija, Fakultet medicinskih nauka, Katedra za hirurgiju
}

\section{ABSTRACT}

Intracranial aneurisms are ongoing problem for neurosurgeons and especially for interventional neuroradiologists due to its morbidity and mortality. The method of choice for treatment of the unruptured and ruptured intracranial aneurysms is endovascular coiling on account of its minimal invasiveness and high effectiveness. The aim of our study was to evaluate the safety and successfulness of endovascular coiling procedure in unruptured and ruptured intracranial aneurysms.

Our study was designed as case series and consisted of patients older than 18 years, who underwent endovascular coiling of unruptured and ruptured intracranial aneurysms and follow-up examination 6 months after the interventional procedure. The procedures were performed from December 2010 to December 2016, by experienced interventional neuroradilogists (more than 400 performed embolizations each) at the Department for Interventional Neuroradiology, Clinical Center Kragujevac, Serbia.

There were 681 patients (average age $47.5 \pm 11.2$ years) treated with endovascular coiling, out of them 324 (234 females, 90 males) had unruptured intracranial aneurysm and 357 (138 females, 219 males) had ruptured intracranial aneurysm. In our series, total complication rate was 11.71 $\%$. Analysis of the results after first endovascular procedure has shown that complete aneurysm occlusion was accomplished in 546 patients (80.3\%), near-complete in 81 patients (11.8\%), and incomplete in 54 patients (7.9\%).

Our results were satisfying regarding the procedure's success, safety, outcomes and study material. However, further technical development of the materials and constant training of the interventional radiologists, are a necessity in order to improve treatment outcomes and patients' benefit.

Key words: endovascular coil, embolization, intracranial aneurysm, safety, complication, evaluation

\section{SAŽETAK}

Intrakranijalne aneurizme su problem kako za neurohirurge, tako $i$ za interventne neuroradiologe zbog svog morbiditeta $i$ mortaliteta. Metoda izbora za lečenje nerupturiranih $i$ rupturiranih intrakranijalnih aneurizmi je endovaskularni koiling zbog minimalne invazivnosti $i$ visoke efikasnosti. Cilj naše studije je bio da se proceni bezbednost $i$ uspešnost procedure endovaskularnog koilovanja kod nerupturiranih $i$ ruptiranih intrakranijalnih aneurizmi.

Naša studija je dizajnirana kao serija slučajeva i sastojala se od pacijenata starijih od 18 godina, koji su podvrgnuti endovaskularnom koilovanju nerupturiranih $i$ rupturiranih intrakranijalnih aneurizmi i naknadnom pregledu 6 meseci nakon interventne procedure. Procedure su sprovedene od decembra 2010. do decembra 2016. godine od strane iskusnih interventnih neuroradiologa (više od 400 izvedenih embolizacija) na Odeljenju za interventnu neuroradiologiju Kliničkog centra Kragujevac, Srbija.

Bilo je 681 pacijenta lečenih endovaskularnim koilovanjem (prosečna starost $47.5 \pm 11.2$ godina), od kojih je 324 (234 žena, 90 muškaraca) imalo nerupturiranu intrakranijalnu aneurizmu, a 357 (138 žena, 219 muškaraca) je imalo rupturiranu intrakranijalnu aneurizmu. U našoj seriji, ukupna stopa komplikacija bila je $11.71 \%$. Analiza rezultata nakon prve endovaskularne procedure pokazala je da je kompletna okluzija aneurizme izvršena kod 546 pacijenata (80.3\%), skoro-kompletna okluzija kod 81 pacijenta (11.8\%) i nepotpuna okluzija kod 54 pacijenta (7.9\%).

Naši rezultati su zadovoljavajući u pogledu uspeha, bezbednosti, ishoda i studijskog materijala. Medutim, dodatni tehnički razvoj materijala $i$ stalna obuka interventnih radiologa su neophodni u cilju poboljšanja ishoda lečenja $i$ koristi pacijenata.

Ključne reči: endovaskularni koil, embolizacija, intrakranijalna aneurizma, bezbednost, komplikacija, evaluacija 


\section{ABBREVIATIONS}

IA- intracranial aneurysm, SAH - subarachnoid hemorrhaghe, RIA - ruptured intracranial aneurysm,
MR - magnetic resonance,

UIA - unruptured intracranial aneurysm,

PAE-perianeurysmal edema

\section{INTRODUCTION}

Intracranial aneurisms (IA) are ongoing problem for neurosurgeons and especially for interventional neuroradiologists due to its morbidity and mortality. Its prevalence was estimated to be between $0.5 \%$ and $6 \%$, in adults (1). They are multiple in $10-30 \%$ of cases (2). In majority of patients, aneurysm ruptures which results in subarachnoid hemorrhage (SAH) (3). In developed countries, such as United States, around 27000 new patients with SAH after ruptured intracranial aneurysm (RIA) occur, while the incidence of SAH in the western countries is around 6-10 per 100000 inhabitants per year $(4,5)$. In Serbia the incidence of rupture and SAH goes between 8 to 10 per 100 000 inhabitants per year (5). These patients ussually come with "sudden severe headache of atypical quality“, coma or severe neurologic disfunction, but they can also have mild clinical presentation $(6,7)$. Cerebrospinal fluid examination and imaging with magnetic resonance (MR) imaging and MR angiography are used as diagnostic modalities (5). Still, mortality rates after subarachnoid hemorrhage are around $40 \%$ and due to this fact, diagnosis and treatment of intracranial aneurysm before the rupture are cruical (8).

Diagnose of the unruptured intracranial aneurisms (UIA) is growing due to the increasing use of modern imaging modalities $(9,10)$. The prevalence of UIA is around $1-7 \%$, and some authors suggest that $30 \%$ of general population has an UIA $(8,11)$. These patients present with palsies of the cranial nerves or brain stem compression (2). Most of the UIA are small (65-85\%), with diameter less than $5 \mathrm{~mm}$ or up to $7 \mathrm{~mm}$ in diameter and they have the risk of rupture less or qual than $1 \%$ per year (12). The rupture of the UIA is rare, but high in mortality (13). It was noticed that there is a raise of cost associated with the diagnosis and treatment of the UIA in the United States (14). This was due to the expanded use of MR angiography and computed tomography angiography $(12,14)$.

The method of choice for treatment of the unruptured and ruptured intracranial aneurysms is endovascular coiling on account of its minimal invasiveness and high effectiveness $(3,4,14,15)$. This technique is presented by Gugliemi's discovery of detachable coils and the essence of the procedure is to exclude the aneurysm from the circulation by use of detachable coils after suitable placement of a microcatheter in the aneurysm $(11,16)$. It is proven that endovascular embolization shortens hospitalization length and improves recuperation on account of its ability to prevent aneurismal rupture and intracranial hemorrhage (17). Because of that more advanced way of treatment was de- signed in the form of bioactive coils (18). However, despite its effectiveness, the treatment is occasionally accompanied with perianeurysmal edema (PAE) (15). The relationship between the occurrence of the perianeurysmal edema and use of bioactive coils in the treatment is still under research $(15,17)$. Other complications of the coil embolization are: cerebral vasospasm, artery occlusion, aneurysm perforation, coil migration, thromboembolism etc. (2).

The aim of our study was to evaluate the safety and successfulness of endovascular coiling procedure in unruptured and ruptured intracranial aneurysms.

\section{MATERIALS AND METHODS}

Our study was designed as case series and consisted of patients older than 18 years, who underwent endovascular coiling of unruptured and ruptured intracranial aneurysms and follow-up examination 6 months after the interventional procedure. The procedures were performed by experienced interventional neuroradilogists (more than 400 performed embolizations each) at the Department for Interventional Neuroradiology, Clinical Center Kragujevac, Serbia from December 2010 to December 2016.

The study participants had given written consent before the study onset, and the Ethics Committee of the Clinical Center had approved the study. The Helsinki Declaration as well as applicable guidelines were followed.

Every patient was subjected to digital subtraction angiography of brain, MR imaging of brain and multidetector computed tomography of brain, prior to the interventional endovascular procedure. Treatment strategy was chosen based on the diagnostic images and clinical manifestation. The embolizations were made by „etachable platinum coils: pure platinum, hydrophilic and combination of platinum and hydrophilic coils“. Self-expanding stents were used for prevention of the coil extrusion in aneurysms with broad neck.

The aneurysms were categorized according to their size and location. Technical failure was defined as „an attempted embolization procedure during which coils could not be successfully deployed". Any procedural or other subsequent complication was recorded and analyzed in order to collect information about procedure's safety. The successfulness of the endovascular coils was estimated by initial post-embolization angiography and then by digital subtraction angiography after 6 months, using the following categories: complete occlusion of an 
Figure 1. Ruptured aneurysm on anterior communicating artery, 10 x 8 mm

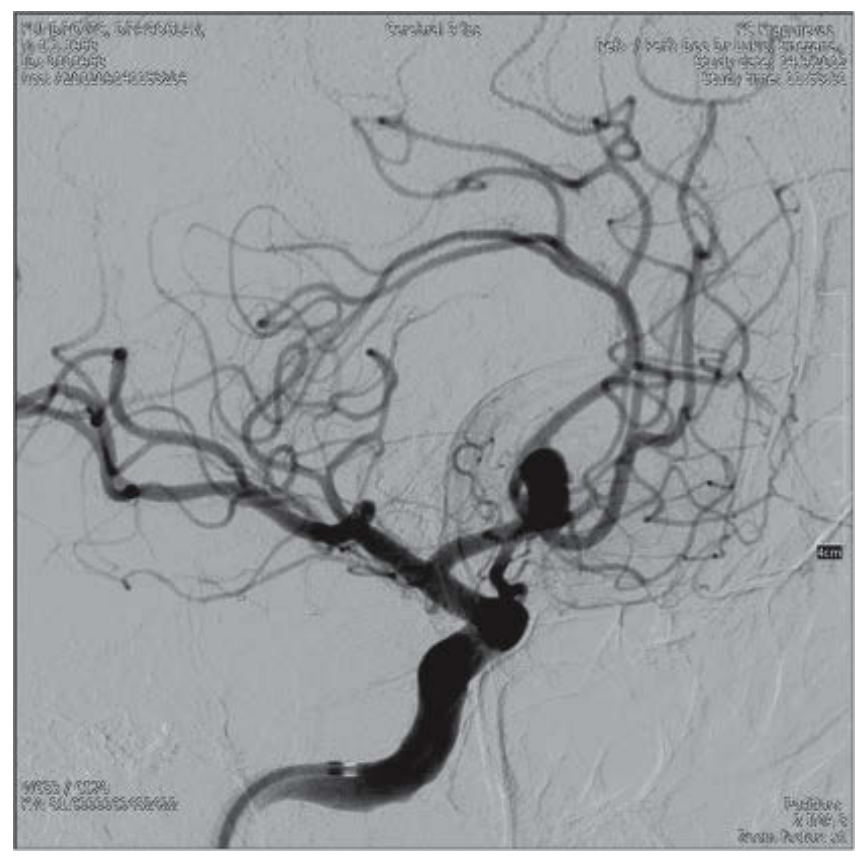

Figure 3. Unrptured aneurysm on left internal carotid artery, $12 \times 10 \mathrm{~mm}$

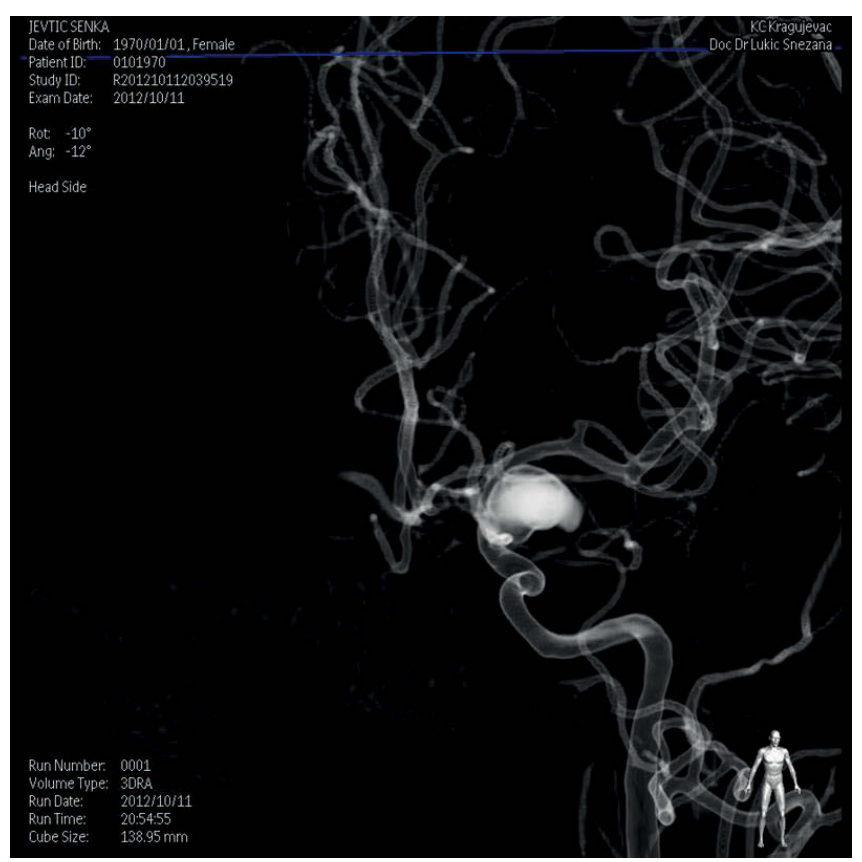

aneurysm (98\%-100\%), near-complete occlusion (90\%$98 \%)$, and incomplete occlusion $(<90 \%)$. Patients were followed after the procedure and Modified Rankin Score was used to determine clinical outcome (scores 0-2: good outcome; scores 3-5: dependency, cannot attend own bodily needs and carry out daily activities without assistance; score 6: death).

Statistical analysis of the data was accomplished with the descriptive statistics, primarily using medians, means and standard deviations for continuous variables, and percentages and odds for categorical variables. The differenc-
Figure 2. Postembolization angiography on same patient as Fig.1

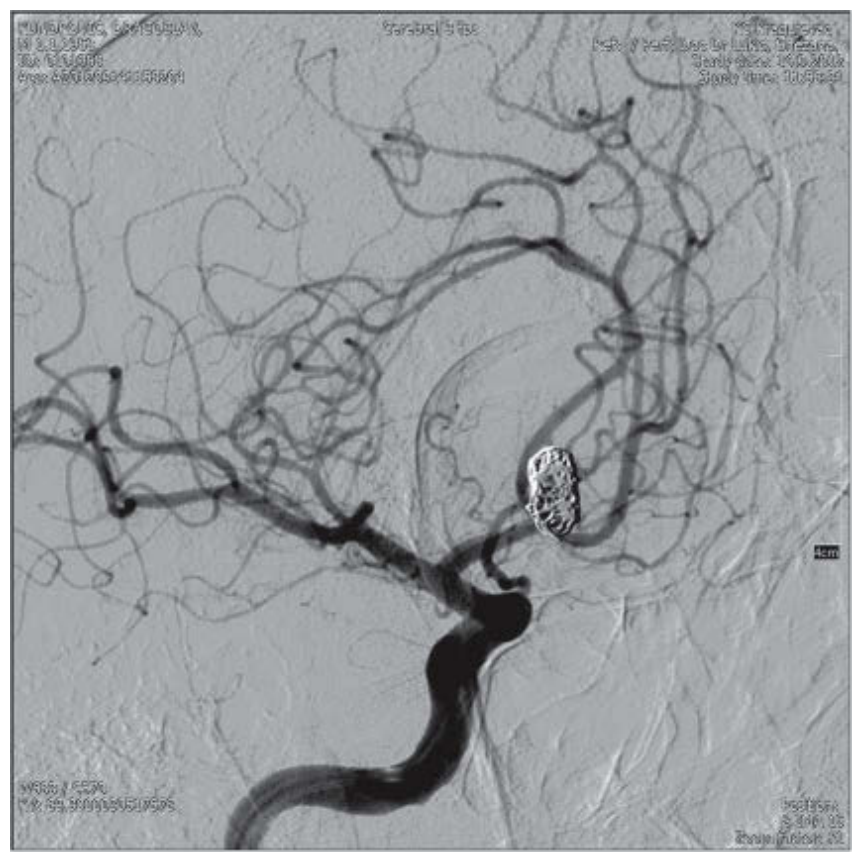

Figure 4. Postembolization angiography on same patient as Fig.3

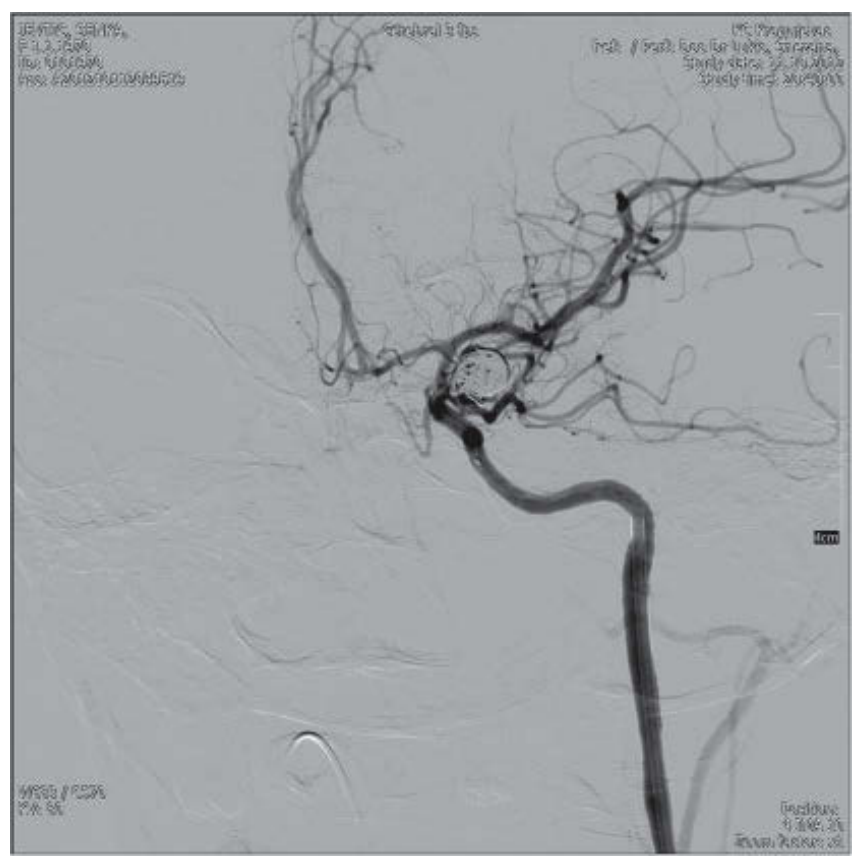

es among study groups were considered significant if the probability of null hypothesis was $<0.05$.

\section{RESULTS}

There were 681 patients (average age $47.5 \pm 11.2$ years) treated with endovascular coiling, out of them 324 (234 females, 90 males) had unruptured intracranial aneurysm and 357 (138 females, 219 males) had ruptured intracranial aneurysm. Figures 1-4 present patients with ruptured and 
Table 1. Aneurysm characteristics and patients' Modified Rankin Score results

\begin{tabular}{|l|c|c|}
\hline & $\begin{array}{c}\text { Number of } \\
\text { patients }\end{array}$ & $\begin{array}{c}\text { Percentage, } \\
\%\end{array}$ \\
\hline Location of ruptured aneurysm & 242 & 35.5 \\
Carotid artery & 93 & 13.6 \\
Middle cerebral artery & 159 & 23.4 \\
Anterior communicating or cerebral artery & 187 & 27.5 \\
Posterior circulation & & \\
\hline Size of aneurysm & 306 & 45 \\
$\leq 10$ mm & 48 & 7 \\
$\geq 25$ mm & 231 & 34 \\
$<15$ mm & 177 & 26 \\
$>15$ mm & & \\
\hline Modified Rankin Score & 531 & 78 \\
Good (score:1-2) & 112 & 16.5 \\
Dependency (score: $3-5)$ & 38 & 5.5 \\
Death (score 6) & \multicolumn{2}{|l}{} \\
\hline
\end{tabular}

unruptured aneurysms before and after endovascular coiling procedure. Also, mean aneurysm size was calculated to be $18.85 \mathrm{~mm}$ in diameter. Location of the aneurysm, its size and Modified Rankin Sore are presented in Table 1.

Technical success of the procedure was assessed by the evaluation of the procedure and after 6 months examination. Analysis of the results after first endovascular procedure has shown that complete IA occlusion was accomplished in 546 patients (80.3\%), near-complete in 81 patients $(11.8 \%)$, and incomplete in 54 patients $(7.9 \%)$. These rates were also investigated after six months and it was determined that complete occlusion persisted in 528 patients, near-complete in 75 patients, and incomplete in 38 patients. In thirty eight patients, outcome was death. Occlusion rate was investigated depending on the aneurysm size. Our results revealed that the complete occlusion was successful in all patients with aneurysms $<10$ $\mathrm{mm}$ in diameter, after first endovascular treatment and after 6 months of follow-up. Nevertheless, angiograms of aneurysms $>10 \mathrm{~mm}$ in diameter have shown that after 6 months, 35 patients had recanalization of the aneurysm, even though their aneurysms were completely occluded after the first procedure. The endovascular coiling procedure in this study led to a significant decrease in aphasia, confusion and frequency of motor deficit in the upper and lower extremities.

Procedure safety was estimated based on the occurrence of the coiling complications. In our series, total complication rate was $11.71 \%$. Death rate was $5.5 \%$. The occurrence of individual complications, due to the endovascular coiling procedure are presented in Table 2.

\section{DISCUSSION}

It has been published by several authors that endovascular embolization of intracranial aneurysms with detachable coils is an effective method for patients' treatment
Table 2. Occurrence of the endovascular coiling procedure complications

\begin{tabular}{|l|c|c|}
\hline & $\begin{array}{c}\text { Number of } \\
\text { patients }\end{array}$ & $\begin{array}{c}\text { Percentage, } \\
\%\end{array}$ \\
\hline Perianeurysmal edema & 248 & 36.4 \\
\hline Symptomatic perianeurysmal edema & 44 & 6.5 \\
\hline Cerebral vasospasm & 195 & 28.6 \\
\hline Thromboembolism & 20 & 3 \\
\hline Artery occlusion & 3 & 0.4 \\
\hline Aneurysm perforation & 2 & 0.3 \\
\hline Coil migration & 0 & 0 \\
\hline
\end{tabular}

$(19,20)$. Previously, the golden standard for the treatment of IA was surgical clipping (21). Thanks to the technical advancement, this conception has changed and interventional procedures have found their way in this field $(20,22)$. Gugliemi's discovery of detachable coils brought the opportunity to treat the patients with IA more efficiently and more effective (16). This technique as previously described has its complications.

Different studies have shown that their mortality rates varied from $0.6 \%$ to $29 \%(4,23,24)$. One of the published studies had presented that death rate of patients with IA who underwent coil embolization was $6.21 \%$ (25). This study was performed on both ruptured and unruptered intracranial aneyrisms and it stated that $1.74 \%$ of deaths was due to the technical complications and in $4.47 \%$ of patients the main cause of death was severity of the hemorrhage (25). In our series, mortality rate was $5.5 \%$ which is a good result compared to the published literature and is in good accordance comparing to the other studies (23-25).

The coils embolization outcomes were compared with the surgical treatment and it was found, by the other authors, that the risk of significant disability was $22.6 \%$ lower, as well as risk of death in favour of coiling procedure $(2,13)$. Our case series showed good clinical outcome, as $78 \%$ of patients had grade 1 or 2 on Modified Rankin Score, which is in accordance with previous studies (Jahromi: 63\% and Sluzewski: 84\% ) $(19,26)$. Also, all of our patients with small aneurysms (less than 10 $\mathrm{mm}$ ) had successful treatment, while larger aneurysms demonstrated predisposition for new coiling. This was justified with the aneurysm size and their closeness to the large blood vessels which is delicate factor that may lead to extensive ischemia after potential compression.

Our study has also evaluated the complications of the procedure. In our series complication rate was $11.71 \%$, which is similar with previous studies (12.4\%) (27). We have shown that none of the patients with incomplete occlusion had repeated rupture after six month follow-up examination, which may be due to the smaller sample size than previous study which reported that $1 \%$ out of 1005 patients had rebleeding (28). It was also shown that the risk of rebleeding is around $1.4 \%$ by another study (11). Our rate of the perianeurysmal edema is in agreement with previously published papers in which PAE rate was $33.3 \%$ of all cases (29). Also, our symptomatic PAE rate was 
$6.5 \%$, and other studies have shown that this rate can be very small or it goes up to $14.3 \%(15,30)$.

In conclusion, our results were satisfying regarding the procedure's success, safety, outcomes and study material. The material that is used for the endovascular procedures has relevant role in the treatment of patients with intracranial aneurysms. However, further technical development of the materials and constant training of the interventional radiologists, are a necessity in order to improve treatment outcomes and patients' benefit.

\section{ACKNOWLEDGMENT}

This work was supported by grant from the Faculty of Medical Sciences, University of Kragujevac (project JP 03-13).

\section{REFERENCES}

1. Schievink WI. Intracranial aneurysms. N Engl J Med 1997; 336: 28-40.

2. Debrun GM, Aletich VA, Thornton J, Alazzaz A, Charbel FT, Ausman JI, et al. Techniques of coiling cerebral aneurysms. Surg Neurol 2000; 53: 150-6.

3. Suarez JI. Treatment of ruptured cerebral aneurysms and vasospasm after subarachnoid hemorrhage. Neurosurg Clin N Am 2006; 17:57-69.

4. Hamid RS, Tanveer-ul-Haq, Chishti I, Azeemuddin M, Sajjad Z, Salam B. Treatment of intracranial aneurysms using detachable coils; initial results at a university hospital in Pakistan. J Pak Med Assoc 2010;60(8):638-41.

5. Lukić S, Mijailović M, Marković Z, Janković SM, Nikolić R. Embolization of ruptured intracranial aneurysms with detachable coils: case series. Jpn J Radiol 2011; 29(2):92-7. doi: 10.1007/s11604-010-0519-9.

6. Ostergaard JR. Headache as warning symptom of impending aneurysmal subarachnoid hemorrhage. Cephalalgia 1991;11: 53-5.

7. Landtblom AM, Fridriksson S, Boivie J, Hillman J, Johansson G, Johansson I. Sudden onset headache: a prospective study of features, incidence and causes. Cephalalgia 2002; 22:354-60.

8. Ji W, Liu A, Lv X, Kang H, Sun L, Li Y, Yang X, Jiang C, Wu Z. Risk Score for Neurological Complications After Endovascular Treatment of Unruptured Intracranial Aneurysms. Stroke 2016; 47(4):971-8. doi:10.1161/ STROKEAHA.115.012097.

9. Thompson BG, Brown RD Jr, Amin-Hanjani S, Broderick JP, Cockroft KM, Connolly ES Jr, et al; American Heart Association Stroke Council, Council on Cardiovascular and Stroke Nursing, and Council on Epidemiology and Prevention; American Heart Association; American Stroke Association. Guidelines for the management of patients with unruptured intracranial aneurysms: a guideline for healthcare professionals from the American Heart Association/American Stroke Association. Stroke 2015; 46:2368-2400. doi: 10.1161/ STR.0000000000000070.
10. Brown RD Jr, Broderick JP. Unruptured intracranial aneurysms: epidemiology, natural history, management options, and familial screening. Lancet Neurol 2014; 13:393-404. doi: 10.1016/S1474-4422(14)70015-8.

11. Jalbert JJ, Isaacs AJ, Kamel H, Sedrakyan A. Clipping and Coiling of Unruptured Intracranial Aneurysms Among Medicare Beneficiaries, 2000 to 2010. Stroke 2015; 46(9):2452-7. doi: 10.1161/STROKEAHA.115.009777.

12. Juvela S, Poussa K, Lehto H, Porras M. Natural history of unruptured intracranial aneurysms: a long-term follow-up study. Stroke 2013; 44(9):2414-21. doi: 10.1161/ STROKEAHA.113.001838.

13. Etminan N, Brown RD Jr, Beseoglu K, Juvela S, Raymond J, Morita A et al. The unruptured intracranial aneurysm treatment score: a multidisciplinary consensus. Neurology 2015; 85(10):881-9. doi:10.1212/ WNL.0000000000001891.

14. Huang MC, Baaj AA, Downes K, Youssef AS, Sauvageau E, van Loveren HR, et al. Paradoxical trends in the management of unruptured cerebral aneurysms in the United States: analysis of nationwide database over a 10-year period. Stroke 2011; 42:1730-1735.

15. Lukic S, Jankovic S, Popovic KS, Bankovic D, Popovic P, Mijailovic M. Analysis of risk factors for perifocal oedema after endovascular embolization of unruptured intracranial arterial aneurysms. Radiol Oncol 2015; 49(4):341-6. doi: 10.1515/raon-2015-0044.

16. Guglielmi G, Vinuela F, Dion J, Duckwiler G. Electrothrombosis of saccular aneurysms via endovascular approach. Part 2: Preliminary clinical experience. J Neurosurg 1991; 75: 8-14.

17. Horie N, Kitagawa N, Morikawa M, Tsutsumi K, Kaminogo M, Nagata I. Progressive perianeurysmal edema induced after endovascular coil embolization. Report of three cases and review of the literature. J Neurosurg 2007; 106: 916-20.

18. White JB, Cloft HJ, Kallmes DF. But did you use HydroCoil? Perianeurysmal edema and hydrocephalus with bare platinum coils. Am J Neuroradiol 2008; 29: 299-300.

19. Sluzewski M, van Rooij WJ, Rinkel GJ. Wijnalda D. Endovascular treatment of ruptured intracranial aneurysms with detachable coils: long term clinical and serial angiographic results. Radiology 2003; 227:720-4.

20. Piotin M, Spelle L, Mounayer C, Salles-Rezende MT, Giansante-Abud D, Vanzin-Santos R, et al. Intracranial aneurysms: treatment with bare platinum coils-aneurysm packing, complex coils, and angiographic recurrence. Radiology 2007; 243:500-8.

21. Horowitz MB, Levy E, Kassam A, Purdy PD. Endovascular therapy for intracranial aneurysms: a historical and present status review. Surg Neurol 2002; 57: 147-58.

22. Wanke I, Doerfler A, Dietrich U, Egelhof T, Schoch B, Stolke D, et al. Endovascular treatment of unruptured intracranial aneurysms. AJNR Am J Neuroradiol 2002; 23: 756-61. 
23. Van Rooij WJ, Sluzewski M. Procedural morbidity and mortality of elective coil treatment of unruptured intracranial aneurysms. AJNR Am J Neuroradiol 2006; 27: 1678-80.

24. Lanterna LA, Tredici G, Dimitrov BD, Biroli F. Treatment of unruptured cerebral aneurysms by embolization with guglielmi detachable coils: case fatality, morbidity, and effectiveness in preventing bleeding--a systematic review of the literature. Neurosurgery 2004; 55: 767-75.

25. Viñuela F, Duckwiler G, Mawad M. Guglielmi detachable coil embolization of acute intracranial aneurysm: perioperative anatomical and clinical outcome in 403 patients. J Neurosurg 2008; 108: 832-9.

26. Jahromi BS, Mocco J, Bang JA, Gologorsky Y, Siddiqui $\mathrm{AH}$, Horowitz $\mathrm{MB}$, et al. Clinical and angiographic outcome after endovascular management of giant intracranial aneurysms. Neurosurgery 2008; 63: 662-74.

27. Renowden SA, Benes V, Bradley M, Molyneux AJ. Detachable coil embolisation of ruptured intracranial aneu- rysms: a single center study, a decade $640 \mathrm{~J}$ Pak Med Assoc experience. Clin Neurol Neurosurg 2009; 111: 179-88.

28. Molyneux A. Present status of endovascular treatment: ISAT. Part II. Presented at the 4th conference course: intracranial aneurysms: from diagnosis to treatment. Leiden, The Netherlands, October 2004.

29. Dengler J, Maldaner N, Bijlenga P, Burkhardt JK, Graewe A, Guhl S et al; Giant Intracranial Aneurysm Study Group. Perianeurysmal edema in giant intracranial aneurysms in relation to aneurysm location, size, and partial thrombosis. J Neurosurg 2015; 123(2):446-52. doi: 10.3171/2014.

30. Sim KJ, Yan B, Dowling RJ, Mitchell PJ. Intracranial aneurysms with perianeurysmal edema: long-term outcomes post-endovascular treatment. J Neuroradiol 2015; 42(2):72-9. doi: 10.1016/j.neurad.2014.05.001. 